\title{
Determinants of Livelihood Diversification: A Case Study of Tribal Households in Kinnaur District of Himachal Pradesh
}

\author{
Gagan Mehta, R.S. Prasher, Amit Guleria' and Nisha Devi \\ Department of Social Sciences, Dr. Y.S. Parmar University of Horticulture and Forestry, Nauni, Solan-173 230, India \\ ${ }^{1}$ Department of Economics and Sociology, Punjab Agricultural University, Ludhiana-141 004, India \\ Email: gagan.mehta14@gmail.com
}

\begin{abstract}
Livelihood is a multifarious concept referring to what people do to manage revenue for living with the assets at their disposal and what they achieve by doing it in a particular context. In the past decades, livelihood diversification has received much attention from researchers and policy makers with high hopes that promoting it can offer a pathway for poverty reduction and economic growth. Therefore, an attempt has been made in this paper to identify the determinants of livelihood diversification of the tribal people using primary data collected based on multistage random sampling from 120 households of Kinnaur, one of the remote districts of Himachal Pradesh. The Simpson livelihood diversification index was found higher for salaried group as well as Agriculture+ Services group. Out of the 9 determinants of diversification of livelihoods identified, level of education, access to irrigation, membership and training have positive and significant effect on livelihood diversification activities. However, land-man ratio has negative and significant correlation with livelihood diversification sources. Therefore, the findings of this study implies that development policies in the region should consider education, skill generation, membership of formal organization and better irrigation facilities as the key areas for the better development and diversification of tribal households.
\end{abstract}

Keywords: Livelihood diversification, Tribal households, Simpson index, Determinants, Multiple regression analysis

In present era, the problem of livelihood has become a major concern among tribal communities. The inability to meet basic needs and goals forces many rural households to pursue a strategy of diversifying their economic activities. A surfeit of studies from developing countries have underscored the importance of diversification strategies from farm to non-farm activities which have immense potential to enhance farmers' income and alleviate conditions of poverty and inequality (de Janvry et al 2005, Reardon et al 2007). The livelihood among tribal communities in India is complex, dynamic and multidimensional phenomenon, perception of which varies with geographic location, type of community, age, gender, education, infrastructure, social, economic, cultural, ecological and political determinants (Kumar 2009). Agriculture constitutes main sources of livelihood among tribes in India playing a vital role in national economy, rural development, employment and occupation, agro-industries, food and nutritional security, growth and survival, social, economic and cultural conditions and poverty alleviation (Surayya et al 2008). About 70 per cent of the population mainly depends on rain fed agriculture characterized by low productivity, un-predictive weather and calamities, degraded soil with low fertility, un- protective irrigation and degraded natural resources (Chakraborty et al 2009). These factors aggravated the problems of poverty, migration, unemployment, underemployment, food insecurity and malnutrition for millions of tribal people in India. The linkages between tribal people, livelihood dependence on different resources and poverty are complex and require locallyspecific analysis. Kinnaur is among the remote and high altitude districts of the state. On account of the high altitude and resultant cold-arid climate, it is among the environmentally very difficult regions to live in. Kinnaur was a restricted area till early 1990s this resulted in stepped up initiatives for socio economic development with the objective to broaden their social horizon and bring economic contentment among the people who till then were backward and formed a closed society. In order to understand the contribution and potential of different resources/assets to tribal livelihoods, poverty reduction, socio-economic upliftment, nutritional security, environmental conservation and rural development, it's changing pattern and reasons for changes, it is imperative to design a research plan based on multi- disciplinary approaches. Keeping the above facts in view, the present study was undertaken in Kinnaur District of Himachal Pradesh.

\section{MATERIAL AND METHODS}

This study was conducted in the Kinnaur district of North- Western Himalayan region of Himachal Pradesh stretching from $\mathrm{N}$ latitude $31^{\circ} 05^{\prime} 50^{\prime \prime}$ and $32^{\circ} 05^{\prime} 15^{\prime \prime}$ and $\mathrm{E}$ longitude $77^{\circ} 45^{\prime} 00^{\prime \prime}$ and $79^{\circ} 00^{\prime} 35^{\prime \prime}$. The sample of 
respondents for the study was drawn using a multistage random sampling procedure. Kinnaur district is divided into three developmental blocks, two of which were chosen at random for this study. A comprehensive list of panchayats was compiled, and three panchayats were chosen at random from each block. Following the selection of three panchayats, a comprehensive list of villages was compiled with the assistance of the panchayat secretary, and two villages from each panchayat were chosen at random. As a result, six villages from each block were chosen for the current study. A comprehensive list of the households in the selected villages was compiled, and 10 households were chosen at random from each village. Thus, a total of 120 households were chosen for the current study, and these households were then divided into four livelihood groups depending on their source of income: Agriculture, Salaried, Agriculture + Business, and Agriculture + Services.

\section{Analytical Tools}

Livelihood diversification index: There are a variety of indicators, and indices to measure livelihood diversification like number of income sources and their share, Simpson index, Herfindahl index, Ogive index, Entropy index, Modified Entropy index, Composite Entropy index (Shiyani and Pandya 1998, Khatun and Roy 2012). The Simpson index was chosen for this investigation because of its computational simplicity, robustness, and wide applicability.

$$
\text { S.I } .=1-\sum_{i=1}^{N} \mathrm{Pi}^{2}
$$

Where, $\mathrm{N}$ is the total number of income sources and $\mathrm{P}_{\mathrm{i}}$ represents income proportion of the i-th income source. Its value lies between 0 and 1 . The value of the index is zero when there is a complete specialization and approaches one as the level of diversification increases.
Determinants of livelihood diversification: The livelihood diversification index was hypothesized to be a function of number of factors including age, education, family size, dependency ratio, land-man ratio, asset value, irrigation facility, training/ skill development and social organization membership. Among these determinants of livelihood diversification, educational level, dependency ratio, family size, asset value, irrigation, membership and training were hypothesized to be positively correlated with livelihood diversification. The households with higher level of education, high dependency ratio, larger family size, stronger asset base and well access to irrigation facilities, better cooperative participation and better access to skill development programmes in the study area are expected to have more diversified livelihood. The age of household heads was inversely related with livelihood diversification, implying that households with a younger head will have more desire and access to non-farm activities. Furthermore, land-man ratio was also hypothesised to be negatively correlated with livelihood diversification, implying that lower the value of land-man ratio, more will be the pressure on land, which leads to disguised unemployment in agriculture, forcing surplus labour to seek work in the non-farm sector thereby diversifying their livelihood (Table 1).

Regression analysis: Multiple regression analysis was used to determine the primary factors of livelihood diversification using Equation (1):

$$
D=\beta_{0}+\beta_{i} X_{i}+\mu
$$

Where, $D$ is the dependent variable representing Livelihood Diversification Index, explained by $\beta_{i}$ which represents a vector of parameters, and $X_{i}$ is a vector of exogenous explanatory variables. Descriptions of the

\begin{tabular}{|c|c|c|}
\hline Variable name & Definition & $\begin{array}{l}\text { Expected sign } \\
\text { of coefficients }\end{array}$ \\
\hline LDI & Livelihood diversification index (Simpson *100) & \\
\hline Age & Actual age of household-head in years & - \\
\hline Dependency ratio & Percentage of household members below 14 and above 65 years & + \\
\hline Education & Literacy rate of each household & + \\
\hline Family size & A household's total number of members & + \\
\hline Land-man ratio & Cultivable land per working member in a household (ha) & - \\
\hline Asset value & A household's estimated worth of all physical assets (excluding land) and livestock worth (in rupees) & + \\
\hline Irrigation & Percentage area irrigated & + \\
\hline Membership & $\begin{array}{l}\text { Dummy, if a household belongs to a formal social organisation such as a SHG/Co-operative/Village } \\
\text { Committee, and so on. }\end{array}$ & + \\
\hline Training & Dummy, has a family member received any official training in the development of livelihood skills? & + \\
\hline
\end{tabular}
explanatory variables are given in Table 1.

Table 1. Description of explanatory variables used in regression analysis 


\section{RESULTS AND DISCUSSION}

The main livelihood groups, their level of livelihood diversification, and the contribution of various sources of income in the research region indicates the highest level of diversification is in the Salaried and Agriculture+ Services groups (Table 2). The Agricultural Groups' livelihoods are less diverse in general. Agriculture+ Services and Agriculture+ Business are in a better position, perhaps due to their stronger asset base.

Regression analysis: The result of the multiple regression revealed that education, land man ratio, irrigation, membership and training are significant determinants of livelihood diversification in the study area, whereas the rest four explanatory variables are insignificant i.e. they have no significant impact on livelihood diversification in the study area (Table 3).

In contrary to research hypothesis, the co-efficient for age is positive and statistically insignificant. Furthermore, the dependency ratio is positively related with the level of diversification, but the co-efficient was statistically nonsignificant. Educational level was one of the most important predictors of livelihood diversification, with a positive correlation and significance. Education is a significant barrier to participation in the non-farm economy in Kinnaur for salaried positions and petty business. This shows that highly educated people diversify their livelihood alternatives by choosing salaried jobs, self-employment, and other activities, whereas low-educated and illiterate people rely solely on wage labour. Investing in education and increasing access to higher education will assist tribal households in obtaining alternate sources of income. Increased educational level will increase the likelihood of participation in non-farm activities in rural areas and diversification of livelihoods. The findings of this investigation are in line with previous findings (Nghiem 2010, Khatun and Roy 2012, Agyeman et al 2014 and Khan et al 2017).

Family size was positively associated to the level of livelihood diversification, which was in line with our expectations, but the co-efficient was not statistically significant. But land-man ratio was an important and statistically significant factor of livelihood diversification and the relationship between the land-man ratio and diversification level was found to be negative as per the hypothesis. This implies that a drop in its value puts undue pressure on land, resulting in disguised unemployment in agriculture (i.e., workers having very low or zero marginal productivities). The surplus labour will seek employment in the non-farm sector. The co-efficient of irrigation was significant determinant and positively related to livelihood diversification in the study area. Majority of people in the study area are involved in production and sale of various vegetable and fruit crops such as peas, cauliflower, potato, cabbage apple. Therefore availability of proper irrigating facilities boosts up the production and increase returns from sale of these crops there by generating more income which can be diverted to other non-farm activities leading to increase in livelihood diversification. The results of the study are consistent with the findings of Khatun and Roy (2012) and Ambachew and Ermiyas (2016).

The relationship between livelihood diversification and

Table 3. Parameter estimates of multiple regression result

\begin{tabular}{|c|c|c|c|}
\hline Parameters & Coefficients & Standard Error & t Stat \\
\hline Intercept & 0.609 & 0.165 & 3.698 \\
\hline Age & 0.001 & 0.001 & 0.094 \\
\hline Dependency ratio & 0.017 & 0.069 & 0.245 \\
\hline Education & $0.002^{*}$ & 0.001 & 1.768 \\
\hline Family size & 0.009 & 0.009 & 1.081 \\
\hline Land man ratio & $-0.042^{* *}$ & 0.021 & 1.996 \\
\hline Irrigation & $0.001^{*}$ & 0.001 & 1.683 \\
\hline Membership & $0.078^{* * *}$ & 0.024 & 3.223 \\
\hline Training & $0.088^{* * *}$ & 0.024 & 3.742 \\
\hline Assets & 0.001 & 0.000 & 1.250 \\
\hline $\mathrm{R}^{2}$ & & 0.33 & \\
\hline $\mathrm{F}$ & & 6.18 & \\
\hline
\end{tabular}

No. of observations 120

Note: ${ }^{*}{ }^{* *}$ and ${ }^{* * *}$ denote significance at 10,5 and $1 \%$ level of significance

Table 2. Level of livelihood diversification and income sources for different livelihood groups in Kinnaur district

\begin{tabular}{lcccccccc}
\hline Livelihood groups & $\begin{array}{c}\text { Simpson } \\
\text { index }\end{array}$ & $\begin{array}{c}\text { Average income } \\
\text { (Rupees)/HH/year }\end{array}$ & \multicolumn{4}{c}{ Share of different activities in household income (\%) } \\
\cline { 5 - 9 } & & & $\begin{array}{c}\text { Agriculture (including } \\
\text { horticulture, forestry) }\end{array}$ & $\begin{array}{c}\text { Livestock } \\
\text { rearing }\end{array}$ & Business & Handicrafts & Salaried & Others \\
\hline Agriculture & 0.15 & 357612 & 92.77 & 6.34 & 0.04 & 0.86 & 0.00 & 0.00 \\
Salaried & 0.54 & 509808 & 32.08 & 5.03 & 1.72 & 1.96 & 58.85 & 0.37 \\
Agriculture + Business & 0.32 & 539897 & 80.49 & 4.38 & 15.13 & 0.00 & 0.00 & 0.00 \\
Agriculture + services & 0.52 & 789921 & 57.33 & 3.32 & 1.13 & 0.00 & 38.51 & 0.00 \\
All occupations & 0.23 & 433775 & 83.65 & 5.71 & 2.14 & 0.74 & 7.77 & 0.02 \\
\hline
\end{tabular}


membership of a cooperative society was positive and statistically significant. Membership in multiple self-help groups (SHGs) boosts a person's social status and allows them access to common property resources as well as a variety of government and non-governmental organisation (NGO) programmes in the studied region. The outcome of the study is in line with Khatun and Roy findings (2012). The relation between skill enhancing training and level of diversification are positive and significant. Strong influence of this factor on livelihood diversification might be contributed to the various training programmes/schemes undergoing in the study area like industrial awareness workshops, Entrepreneurship Development Programme, Poultry Development Schemes, Integrated Handloom Trainings, and Horticulture Development Scheme etc. This implies that human capital in terms of capacity building through skill development help in diversifying livelihoods in rural area. Assets were found to be positively related to the extent of livelihood diversification, but the co-efficient was not significant.

\section{CONCLUSION}

Maximum level of diversification was for Salaried and Agriculture +Service Group and least for Agriculture Group as obtained from Simpson diversification index. This implies that combining different services can help people diversify their income. The multiple regression analysis revealed that among the nine determinants of household livelihood diversification, education level, land-man ratio, irrigation availability, household membership, and training were statistically significant predictors of household livelihood diversification. Therefore, in order to improve the livelihoods and make it more sustainable so as to empowering the tribal households through participatory methods and lift the standard of living of farmers through diversified activities, the implementation of multidimensional policies particularly related to skill generation, irrigation, education, membership through bottom up approach that will develop the capacities, choice, and diversity of livelihoods is deemed vital.

\section{REFERENCES}

Agyeman BAS, Asuming-Brempong S and Onumah EE 2014. Determinants of Income diversification of farm households in the western region of Ghana. Quarterly Journal of International Agriculture 53(1): 55-72.

Ambachew M and Ermiyas A 2016. Determinants of rural household livelihood diversification strategy in South Gondar Zone Ethiopia. Journal of Agricultural Economics Extension and Rural Development 4(8): 548-560.

Chakraborty P, Tiwari HR and Jha MK 2009. Sustainable rural livelihood through participatory natural resource management: A case study. Journal of Rural Development 28(1): 85-100.

De Janvry A, Sadoulet E and Zhu N 2005. The Role of Non-farm Incomes in Reducing Rural Poverty and Inequality in China. Working Paper 1001. Department of Agricultural \& Resource Economics, University of California, Berkley.

Khan W, Tabassum S and Ansari SA 2017. Can diversification of livelihood sources increase income of farm households?: A case study in Uttar Pradesh. Agricultural Economics Research Review 30: 27-34.

Khatun D and Roy BC 2012. Rural livelihood diversification in West Bengal: Determinants and constraints. Agricultural Economics Research Review 25(1): 115-124.

Kumar A 2009. Rural employment diversification in eastern India: Trends and determinants. Agricultural Economics Research Review 22(1): 47-60.

Nghiem LT 2010. Activity and income diversification: Trends, determinants, and effects on poverty reduction. The case of the Mekong River Delta. Ph.D. thesis, International Institute of Social Studies, Netherlands.

Reardon T, Berdegue J, Barrett CB and Stamoulis K 2007. Household income diversification into rural nonfarm activities. In: Haggblade S, Hazell P and Reardon T (eds). Transforming the Rural Non-farm Economy: Opportunities and Threats in the Developing World. Johns Hopkins University Press, Baltimore.

Shiyani RL and Pandya HR 1998. Diversification of agriculture in Gujrat: A spatio-temporal analysis. Indian Journal Agricultural Economics 53(4): 627-39.

Surayya T, Krishna K, Sharma R, Karla S, Kujur SS, Bala S and Basnayat B 2008. Sericulture based micro enterprise as a source of rural livelihood and poverty alleviation: A case study of Anantapur. Journal of Rural Development 27(1): 149-176. 